\title{
Dreiser's Life and Creation: High Perspicacity from Crudity
}

\author{
Limin Bai \\ College of Foreign Languages, Hebei United University, Tangshan 063009, China
}

\begin{abstract}
Theodore Dreiser is a brilliant writer. On the surface he tried to adopt a simple and crude language style and structure style, while under the cover of crudity, Theodore Dreiser presented a different world. It's too realistic and natural to accept by the readers of the age. Theodore Dreiser represented a new and true writing style to show the high perspicacity from crudity.
\end{abstract}

\section{Index Terms-Theodore Dreiser, writing style, American literature}

“... Recalling my past novels, I only can say, Ladies and Gentlemen, such is my description about life... You may not like my description, but the life I have witnessed and felt is just like this. Thus I can only give you such description."

-------Dreiser

In the twentieth century, the nation's political and imaginative path would lie on city streets. The American scene would be urban. The city was embraced by reformers who interpreted the congestion and deprivations of urban life as curable anomalies. More fundamentally many progressives and socialist--- men and women who might be called the new urban ideologist--- believed that the city represented the future and offered democracy. However, Theodore Dreiser's first novel, Sister Carrie (1900) described a primitive and yet decisive account of the city's seductions and dangers. Though hid young title character, Theodore Dreiser expressed his dazzled reaction when he first came to Chicago. He wrote later of that first visit. The city was itself a strange illusion of hope and happiness with its cascade of immigrants, its daily changing skyline, its gargantuan appetites, its mingling of slaughter houses and counting houses. Chicago was perhaps the quintessential American city. This is Chicago which Caroline Meeber sought and dreamed.

As for a member of a publishing house, or his wife, Sister Carrie is "disgusting" Though the book is printed according to the contract, the publishing house doesn't publish it with enthusiasm. Only several are sold. In fact, Carrie Meeber's fate is quite similar with Maggie. But Theodore Dreiser's novel a rouses more trouble in the first ten years after its publishing. Though Maggie displays what Maggie has mistaken is a small one, but at last she still get the end of death. Carrie Meeber, in the last chapter has become famous in New York stage and her future is very good. This infuriate readers, who had been accustomed to mode that women's lives like Carrie Meeber even if there have really been, should not be written out, either. But Theodore Dreiser can't accept those moral and rules contradicting his actual observation.

Theodore Dreiser observes again and over again. Although he describes various details, he can't find the fact that families, friendship or other forms can act as the protection screen in the conflict between individual and environment. As for Theodore Dreiser, "asking him to observe with the usual means and get the result_—such protection screen exists will make no difference with__ asking him to observe a waste and but calling it a plant garden."

Theodore Dreiser was the ill-educated son of impoverished son of impoverished parents, the ninth child of a tyrannically Catholic immigrant father and a more indulgent, illustrate mother to whom he gave such love he would ever feel. The family was mired in poverty and bad luck. The only notable success was that of Theodore Dreiser's older brother Paul did well in show business, Abetted and supported by a local school teacher, he managed to complete a year at Indiana University. There and later, his desultory reading and Nietzsche, Darwin, and Herbert Spencer filled his receptive mind with half-formed, contradictory notions of superman and determinism. Especially in Sister Carrie almost every chapter indicates his understanding of Spencer's thought. Though Spencer's thought influences him very deep in his novel, the thoughts he gets from Spencer has never resulted any interrupted result, never like Norris's naturalist's views makes figure in his writing become dull. Theodore Dreiser's figure comes out of his recollection of his emotion, but not the recollection of thought. In Norris's Macteague the main characters are depicted according to author's life philosophy. While action reflects author's pain in his life, only after narrating the facts, he followed them with some philosophical explanation.

Theodore Dreiser had nothing more in than a little when he jotted the words Sister Carrie at the top of a blank sheet of paper. He made up of her story as he went, appropriating pieces of it from the lives of friends and family, among them, his sister Emma, the dreamer who yearns with an articulate hunger for the glamour that might lift her out of the common place. She realized in a dim way how much the city-held-wealth, fashion, ease--every adornment for women, and she longed for dress and beauty with a whole heart. At the same time, Carrie Meeber is a creature in an allegory of destiny; the first chapter of story is prophetically titled. "The Magnet Attracting: A Waif amid Factory work she quickly finds will yield to only shabbiness and physical pain. She becomes the mistress of two men in turn, the first a flashy salesman, the second a saloon manager named Hurstwood. Caroline Meeber, a girl from countryside, comes to 
Chicago to seek everything she dreamed. But factory work, she quickly finds, will yield only shabbiness and physical pain. She becomes the mistress of two men in turn, the first a glib traveling salesman, the second a saloon manager named Hustwood, who sacrifices his family and reputation to run off with her to New York. The consequence of Carrie's immorality is not punishment or death but a well-paid job on New York stage. It is Hustwood not Carrie, who slides into failure and despair and finally takes his own life by turning on the gas in a flophouse room. Hustwood's suicide is followed by Carrie's concluding meditation, a vague sigh of discontent that is untouched by remorse, though Theodore Dreiser at last tells us that Carrie will never be self-indulgent and satisfied.

Like all of Theodore Dreiser's characters, those in Carrie Meeber obey the dictates of reading rather than literary decorum. The consequence of Carrie's immorality is not punishment or death but a well-paid job on the New York stage. It is Hurstwood, not Carrie, who slides into failure and despair and finally takes his own life by turning on the gas in a flophouse room. Doubleday, to the virtual suppression of a novel that he had initially accepted with enthusiasm. In the much re-arranged version of the novel that Doubleday published, Hurstwood's suicide is followed by Carrie's concluding meditation, a vague sigh of discontent that is untouched by remorse, just as Theodore Dreiser (1992) described in Sister Carrie

"In your rocking chair, by your window, dreaming, shall you long, along. In your rocking-chair, by your window, shall you dream such happiness as you may never feel."'(p382)

However, the author did not show any dissatisfaction about the end of the novel and Carrie. In fact, he was neither approval nor opposed of her. Theodore Dreiser only gave his sympathy to the lost lambs, because he believed: the world is a jungle; why we are here and what is our aim are unknown; we have no rights to choose the environment; it is environment which chooses us and changes us. In his novel this point of view is expressed widely. For example, Carrie Meeber goes here and there to find a job in order to make a living, works in a factory where the condition is lower, and then is seriously ill, thus again loses her job. We can imagine how much she has suffered. It is natural for her to become the mistress of Drute if she wants to live in the city and realizes her dream. The same to Hustwood, he just happens to find the money-locker unlocked. He gets the money. When he changes his mind and wants to put it back, the money-lock has been locked itself. This matter, he can not explain clearly to his boss. Whether willing or unwilling, he has been a thief. In the author's eyes, everyman is the victim of the fate. In order to live on the earth, human being can not be classified into the good and the bad, but only the strong and weak. Everyone is driven by desire. We must struggle and compete cruelly one another.

Carrie Meeber is the seeker, the dreamer, who yearns with an inarticulate hunger for the glamour that might lift her out of the commonplace: "she realized in a dim way how much the city held--- wealth, fashion, easy-every adornment for women, and she longed for dress and beauty with a whole heart." She acts out Theodore Dreiser deduced from his own. Part of Carrie came from his sister Emma, who had eloped with a bartender. Theodore Dreiser was the ninth son of poor parents. His father was a Catholic immigrant and his mother was illiterate but indulgent. He gave his mother all his love that he could feel. The whole family was poor and bad luck except his brother Paul, who made a little success in show business. He completed a year at Indiana University where he learned a lot about Nietzsche, Darwin and Hertbent Spencer. When he was 23, Theodore Dreiser returned to Chicago and began another life as a journalist. He suffered a lot in city life. With the bitter experience of city life and earlier family life Theodore Dreiser saw through the society. Though his work he described the society of that time truthfully. So Carrie Meeber gives readers a true feeling. Such is life. No matter what attitude we held toward it, we cannot escape from it.

As for Hustwood, he actually reflects a kind of social function and a beautified saloonkeeper. He is smooth and well behaved. All of these seem to be his nature, however, it results from his characters. But characters result from his vocation. This result affects his degeneration with bitterness and tragedy. Chicago is a newly developing city and Hustwood belongs to this kind of place. A person like him went to New York is bound to face failure, because New York is a quite developed place. Famous and rich people are here and there. Therefore his desire for Carrie is not the one reason of his decline and his tragic degeneration, that is to say, in Chicago Hustwood is the strong; in New York he becomes the weak, and this is decided by environment but not himself. Human being can not escape himself and his own character. Once Hustwood abandons his own social part in Chicago, and then his tragedies happen one by one. That proves that environment decides man even his character. Man is puny when they face the whole society.

Theodore Dreiser wants to tell such a story. He doesn't need reason. Not any rites and rules can prevent him from telling what he knows. All of this is true, which is his only excuse. If God create these people, he has the right to write them.

How can such a rigid writer not be lonely?

One century ago, Theodore Dreiser trudged in Chicago and wrote the shocking Carrie Meeber, expressing his serious but slight simplified idea. The life and the world he described are credible, among which, various figures are full of the milk of human kindness, making readers' hearts beat together with the figures. Theodore Dreisrer at an end smoothed away numerous difficulties and created a kind of estimable beauty

Although when the publisher's wife read the book, such a fate mode is full of surprises, in the years after 1900, the standard of most American readers has changed unconsciously. Theodore Dreiser's long novel helped him to build a potential reputation. In 1911, his second novel Jenny Girhardt came out. Critics all thought of it as a success. This book was rather popular. Naturalist's writing style stood in a white sheet again. Theodore Dreiser found the new alliance 
amongst the younger writers. During the 20 years after the publishing of Carrie Meeber, it is possible for Willa Cather to write out The Song of Lark, Coming, Aphrodite, and A Lost Lady, which didn't arouse the fury of public. However, people would remember or even should remember it is Carrie Meeber that makes A Lost Lady possible and paved the road for the public to accept any contemporary novels. All of these novels are full of immediate significance. These writers are all serious writers.

"Although he uses such incoherent and blindly-explored language, he enlightens us, and makes us come to realize that he is stronger and sharper, his mind is greater than the world in his writing..." (Alfred Kasin, 1942, p47)

In naturalist writing, characters' motivations are strongly influenced by their environment. Characters behave in a certain way because their environment has a direct effect on how they view the world, themselves, and other people. Naturalist writers try to present what is "real", or truly out there, and do so in terms of the most successful enterprise of the nineteenth century - science, and focus on the things of life as they really are.

As Theodore Dreiser expresses in his Sister Carrie, that he does not show any dissatisfaction about the end of the novel and Carrie. In fact, he is neither approval nor opposed of her. Naturalism was another turn-of-the-century literary movement. By the end of the civil war, northern industrialism had triumphed over southern agrarianism, and from that victory came out a society based on mass labor and mass consumption. Mechanization spread rapidly as steam engines, linked to machines, displaced hand work on farms and factories. The conditions of labor changed for the use new machines, which seemed more valuable and more useful than the workers who tended them. Yet increasing numbers of Americans left the farms to seek jobs in urban factories. However periodic economic depressions, bloody strikes, increasing slums in the cities day by day and various disorders of society made some Americans realized that they did need a new philosophy to explain all of these phenomena.

The local-color movement was a literary movement popular during the 1890s. Local-color writers focused on a particular region of the United States and tried to recreate its culture, dialect, and customs in minute detail. At this time, the United States was still very fragmented culturally, and local-colorists wanted to convey the "quaintness" of a minority culture to mainstream American society. Therefore social Darwinism was spread to America and filled the blank of American knowledge. Darwin disturbed the educated world with his book The Origin of Species. Darwin claimed that change was implicit in the biological world, which over the course of an immense period the competition among living creatures for survival had provided the impetus for change from simpler and more primitive to higher and more complex forms.

The world was not a finished entity created in one blinding flash but a product of evolution, of slow change over time, a process challenged simultaneously a flock of passionately held beliefs. It denied the Judeo-Christian story of the creation of the universe by God in six days, as expressed in Genesis, the first book of the Bible and the semi-divinity of humankind by connecting human beings to the animal world. Thus it made people suspicious of pre-theory and they began to consider how to put Darwinism into every scientific research field in order to discover law of evolution of other things. Therefore there were mechanical materialism and special Darwinism at the time. The famous phase by Spencer is "the fittest survival" According to Darwinism, the so-called society in fact is also a jungle, where is processing the cruel survival competition. Man has no rights to choose his life, and his fate is decided by heredity and environment, physical derives and economic circumstances. Naturalism is based on social Darwinism. Darwin claims the world is a product of evolution. His theory denies the Judeo-Christian story of the creation of the universe by God in six days, as expressed in Genesis, the first book of the Bible and the semi-divinity of humankind by connecting human beings to the animal world.

In naturalist writing, characters' motivations are strongly influenced by their environment. Characters behave in a certain way because their environment has a direct effect on how they view the world, themselves, and other people. Naturalist writers try to present what is "real", or truly out there, and do so in terms of the most successful enterprise of the nineteenth century - science, and focus on the things of life as they really are.

Many writers imitate Stephen Crane of jack London. Theodore Dreiser's writing skills have never been imitated, because there is really nothing to be worth imitating from Theodore Dreiser: confused grammar, sloppy using of word, illogical writing etc. All of these make his novel seem to that he is the unique exception among the writers. Although he has thousands of faults, he sill is great. Theodore Dreiser lacks everything but not talents. He symbolized the originally rough nature of American life.

Like Robinson, holding that attitude of approving the valve and concept of his cultural environment gradually grew up into a writer, but Theodore Dreiser's background is different from Robinson. His Roman Catholic father sent him to the missionary school to study. Thus although the words and sentences of the middle-western dialect have involved to coarseness, what he has learned is more confusedly mingled. The vocabulary he to coarseness, what he has learned is more confusedly mingled. The vocabulary he learned is not small, but whether his family or his education doesn't teacher him to pay more attention to these words. If the two words' meaning are similar any one will be O.K.. He piles the words in the sentences, and doesn't think about the better way of expressing the same things. Later when Theodore Dreiser began to write, he had to pour all his sprits into the materials he wanted to present. He depended on facts to express his intention or meaning but not on dictions. He doesn't use what is irony or the other succinct techniques. Whenever such techniques are needed, that is to say, he should adopt the artistic treatment for the details, Theodore Dreiser uses floods of details. His works always have the sluggish and dull dangers, but actually, they had never been 
like this.

When he was twenty-three, Theodore Dreiser returned to Chicago to cover the Columbian Exposition or the Saint Louis Republic. His writing life for money totally wipes out his concern about quality, although he has no strength to resist the gust of vulgar tide. He was cleared by it. Thus when he writes such serious novel like Carrie Meeber, but this world is so true that anyone, who regards reality, cannot turn a blind eye on it form now on. In spite of various limitations in his skills, Theodore Dreiser makes the great achievement.

Theodore Dreiser is stronger and sharper and has the penetrating insight and foresight. Carrie Meeber is a social prophesy. Today in New York or Hollywood, we can find girls like Carrie here and there. She has become quite familiar figure to people. However, no one stops to make it clear that Theodore Dreiser has discovered the appearance of such kind of people 40 years ago, the motion and the social factors causing them to becoming mature.

As for the structure, this novel is built on the comparison between luxury and poverty. It also gives us a further description on focus of comparison between Carrie's arising and Hurstwood's falling. This novel consists of two person's comparative antecedents through the thorough balanced arrangement. Sister Carrie is typical Naturalist's works lies in that there are no twisted plots caused by ethics and moral. The novel's development doesn't depend on the central character's willingness, but on life rule_ of course, it is no wonder that this is shown by a clever selection of the novelist. Therefore the author doesn't make any suspense. What moves the readers are the life essence but not the emotion evoked by the figure's action? Here, Theodore Dreiser is influenced by Crane, and he plays the tone we hear later in Sherwood Anderson's novels. Theodore Dreiser doesn't let his novel adopt the traditional structure, but offer it with two persons' comparative antecedents. The two antecedents represent the rule of changes. Theodore Dreiser finds this is the tooted process both for life process and nature process.

Theodore Dreiser first of all is a novelist. He has never subordinated human beings' value to philosophical meaning. Readers are interested in Sister Carrie, only because she face the quite similar question with readers, and Hurstwood's degeneration is miserable. However, because of his temperament, readers can accept his failure calmly. Philosopher Theodore Dreiser made a concession to Novelist Theodore Dreiser. The things that happen in the novel must be possible. Thus by the careful arrangements of structure and plots' developments, the writer clearly demonstrates how Hurstwood and Carrie Meeber change. But he mainly wants to discover he vacillate, imprecise and vague nature of experience affected by external force. Such external force is beyond the comprehension of man's experience. In this way, Theodore Dreiser has a little inclination of fatalism, and this point proved that Theodore Dreiser is a Naturalist.

"I acknowledge there is a kind of power, which has nothing with individual's desire or impulse. It is the products of the struggles of various powers. We know nothing about it and certainly can not control it. On the contrary, we are in its grasp, just as the puny sand is swept here and there by storm, with the result that we can't know the aim of doing so." (Thomas King Whipples, 1928, p68)

From the respect of structure, this novel consists of two person's comparative antecedents. Sister Carrie is a typical Naturalism's works lies in there are no twisted plots caused by moral principles. The novel's development doesn't depend on the central character's willingness, but on the life's rule. Theodore Dreiser believed the environment can destroy or change people's moral view toward action, besides he still believed fate is unpredictable and human beings' action is without any meanings and aims. But between the two suffocating beliefs, his view and his belief for life's activity and importance still enlivened. Through Sister Carrie, Theodore Dreiser seemed to say, this is life that I have seen, while I cannot explain why life is in such state but not in the other state. Why blame those wrenched people. They live like that just because such is life.

One century passed. People of the twenty-first century have accepted Sister Carrie with pleasure. Through the thick layers of the book, I gradually feel the heaviness. Theodore Dreiser's hoarse and exhausted shout rings in my car still "such is life! Don't ask me why! Such is what I have witnessed!" Today's China_ China of the twenty-first century, is in a similar situation with America of one century ago. Theodore Dreiser had represented the picture of life, them how we, existing in the picture, adjust ourselves tore-walk into the picture? The writer has no good ideas, therefore you_- people in the picture have to by yourselves to taste, to explore, to ponder...

\section{REFERENCES}

[1] Alfred Kazin. (1942). On Native Grounds. Los Angeles: Back Bay Press.

[2] Burton Rasscoe. (1925). Theodore Dreier. Philadelphia: Mike Brade Company.

[3] Farrell. (1945). Dreiser's Sister Carrie. New York: Pioneer Publishing House.

[4] John Berryman. (1945). Dreiser's Imagination. Boston: H.H.Boyessen Publishing House.

[5] Michael. (1976). Anthology of American Literature Macmillan. New York: Publishing Company.

[6] R.W.B.Lewis. Robert Penn. (1973). Modernists and Muckakers. New York: St.Martin Press.

[7] Theodore Dreiser. (1992). Financier. Beijing: Foreign Language Teaching and Research Press.

[8] Theodore Dreiser. (1992). Sister Carrie. Beijing: Foreign Language Teaching and Research Press.

[9] Thomas King Whipples. (1928). Spoksmen: Modern Writer and American Life. Boston: Abotton Company. 
Limin Bai was born in Shenyang, China in 1977. She received her master's degree in English Language and Literature from Nankai University, Tianjin in 2007.

She is currently a lecturer in the College of Foreign language, Hebei United University, Tangshan, China. Her research interests include American and British literature, culture, translation and English education. 